Check for updates

Cite this: RSC Adv., 2019, 9, 27825

\title{
A novel efficient bioflocculant QZ-7 for the removal of heavy metals from industrial wastewater
}

\author{
Zayed M. M. Abu Tawila, (DD ab Salmah Ismail, ${ }^{* a}$ Salem S. Abu Amr ${ }^{\mathrm{c}}$ and Emad K. Abou \\ Elkhair $^{\mathrm{b}}$ \\ In this study, a novel bioflocculant QZ-7 was produced from Bacillus salmalaya 139SI for industrial \\ wastewater treatment. Biochemical analysis, FTIR, scanning electron microscopy-energy dispersive X-ray \\ spectroscopy, and thermogravimetric analysis were performed. A synthetic wastewater sample was used \\ to validate the performance of the prepared OZ-7 for the adsorption efficiency of $\mathrm{As} \mathrm{Zn}^{2+} \mathrm{Pb}^{2+}, \mathrm{Cu}^{2+}$, \\ and $\mathrm{Cd}^{2+}$ under optimal experimental conditions such as initial metal concentrations, $\mathrm{pH}$, contact time \\ (h) and QZ-7 adsorbent dosage ( $\mathrm{mg} \mathrm{mL}^{-1}$ ). The maximum removal efficiency for $\mathrm{Zn}^{2+}(81.3 \%)$, As (78.6\%), \\ $\mathrm{Pb}^{2+}(77.9 \%), \mathrm{Cu}^{2+}(76.1 \%)$, and $\mathrm{Cd}^{2+}(68.7 \%)$ was achieved using an optimal bioflocculant dosage of \\ $60 \mathrm{mg} \mathrm{L}^{-1}$ at $2 \mathrm{~h}$ shaking time, $100 \mathrm{rpm}$ and $\mathrm{pH}$ 7. Furthermore, the obtained optimum experimental \\ conditions were validated using real industrial wastewater and the removal efficiencies of $89.8 \%, 77.4 \%$ \\ and $58.4 \%$ were obtained for $\mathrm{As}, \mathrm{Zn}^{2+}$ and $\mathrm{Cu}^{2+}$, respectively. The results revealed that the prepared \\ bioflocculant QZ-7 has the capability to be used for the removal of heavy metals from industrial wastewater.
}

Received 22nd June 2019 Accepted 31st July 2019

DOI: $10.1039 / c 9 r a 04683 f$

rsc.li/rsc-advances discharges can increase the concentration of acid and noxious heavy metals. Heavy metals persist in trace quantities in the environment and at small concentrations, they play significant roles in the living organisms; however, they can cause toxicity if their concentrations exceed the recommended level. Toxic metal contamination is considered as one of the pivotal environmental problems, which is generally prevalent in industrialized cities, where the increase in the toxic metal concentration beyond the recommended level can increase many health problems such as carcinogenic diseases and Alzheimer's or Huntington's disease. ${ }^{7}$ For example, heavy metals such as arsenic, lead, mercury, copper, cadmium, nickel, zinc, and chromium act as the primary noxious wastes in fresh water reservoirs because of their harmful, non-biodegradable, and persistent nature. ${ }^{3}$ Industrial development is the basic source of heavy metals that pass through various environment paths, including water, soil, air, and the biosphere. Heavy metals are easily absorbed by seafood, vegetables and eventually by the human body because of their high solubility in the aquatic environment. ${ }^{3}$ The combination of heavy metals with the sulfhydryl groups of proteins prevents enzyme activity, and such combination occurs in contaminated ecosystems, leading to consequences for the human health. ${ }^{8}$ Thus, in living organisms, the strong affinity of arsenite to methanethiol (mercaptan) groups, such as peptides, proteins, and amino acids, involves the types of enzymes that can cause severe noxiousness to humans. ${ }^{9}$ Environmental systems (abiotic methods) have been utilized for removing heavy metals from polluted locations. Abiotic methods include adsorption, the use of activated carbon, reverse osmosis, chemical precipitation, and ion
${ }^{a}$ Institute of Biological Science, Faculty of Science, University of Malaya, 50603, Kuala Lumpur, Malaysia. E-mail: salmah_r@um.edu.my; Tel: +60379672143 ${ }^{b}$ Biology Department, Faculty of Science, Al-Azhar University, Gaza, Palestine ${ }^{c}$ Malaysian Institute of Chemical \& Bioengineering Technology, Universiti Kuala Lumpur, (UniKL, MICET), 78000, Melaka, Malaysia 
exchange. Flocculating materials are commonly applied in numerous fields, including water treatment, fabric industry, cosmetics, drug treatment, and those related to fermentation development. ${ }^{\mathbf{1 0}}$ In literature, several applications and techniques have been reported for industrial wastewater treatment. Several specialists have worked on advanced competent treatment skills. Treatment technologies are principally based on physicochemical, advanced oxidation, or electrochemical methods. ${ }^{4}$ Recently, a biological remediation technique using a permeable reactive barrier (PRB) has been identified as the most cost effective and safe technique; it involves organic, (date seed, Moringa oleifera and wood chips) and inorganic (limestone; $\mathrm{CaCO}_{3}$ ) carbonaceous materials in varying proportions for nitrate $\left(\mathrm{NO}_{3}\right)$ remediation. ${ }^{\mathbf{1 1}}$ Phytoremediation is a potential cost-effective technology for remediating heavy metalcontaminated soils. For example, Pennisetum sp. was found to be the best species for $\mathrm{Cu}$ and $\mathrm{Cd}$ removal. ${ }^{12}$ Also, the biomasses of Elsholtzia splendens and Sedum plumbizincicola were found to be good species for $\mathrm{Cu}$ and $\mathrm{Cd}$ removal. ${ }^{12}$ The obtained results showed that the functionalized halloysite nanotubes enhanced the adsorption capability of the clay mineral and it made nanoclay a good candidate for heavy metal removal from aqueous solutions. ${ }^{13}$ Physicochemical procedures comprise adsorption, ion exchange, membrane filtration, and chemical precipitation. Electrochemical methods are characterized by electro-coagulation, electro-deposition, and electro-flotation. ${ }^{3}$ Photo-catalysis is a unique feature of innovative oxidation techniques. Recently, nanotechnology has been applied in the treatment of wastewater. Among these potential approaches, those with cost-effectiveness, environment-friendliness, and no extra contaminant features are favored. ${ }^{3}$ Flocculant agents are categorized into three groups: organic polymer flocculants, such as polyacrylamide derivatives and polyacrylic acid; inorganic flocculants, such as polyaluminum chloride and aluminum sulfate; and microbial bioflocculants, which include glycoprotein, polysaccharides, and proteins. ${ }^{\mathbf{1 4 , 1 5}}$ Wang et al. $(2011)^{16}$ reported that the flocculants adsorbed onto the surface of suspended particles are essential for the application of vigorous attractive forces to control electrostatic repulsive force. Flocculating methods have an immediate effect on the suspended particle size, that is, a larger size results in more rapid settling down of particles. ${ }^{17}$

Zhang et al. $(2014)^{18}$ reported that the selection of the flocculant type presents a significant effect on the capacity of the flocculating techniques, potency of the accumulated particles, and the degree of bond stability as a consequence of the flocculation process. However, regardless of the significant effectiveness of the flocculating practices in water treatment, the main disadvantage of flocculation is the production of breakable flocs at low temperatures; these flocs can scatter the applied physical force. ${ }^{\mathbf{1}}$

Therefore, "green technology" bioflocculants have attracted increasing methodical and technical consideration in environmental wastewater treatment because they are non-hazardous to humans, possess biodegradable constituents, and become free from pollutants by intermediate deprivation. ${ }^{19}$ In addition, bioflocculants have been generally involved in different applications, such as cleaning up of wastewater, decontamination of organic substance components from sugar, dewatering, dredging, pulp and paper industry, and condensation of mine wastes. $^{14,20}$ A high cost prevents the advancement of bioflocculants for marketable use. ${ }^{1821}$ Therefore, industries of large-scale production and utilization of bioflocculants as prospective alternatives of their artificial counterpart remain to be achieved. The present work aimed to evaluate the potential capability of a polymeric bioflocculant QZ-7 in removing heavy metals from industrial wastewater. In this research, the bioflocculant QZ-7 was produced from Bacillus salmalaya strain 139SI. ${ }^{22}$

Different bioflocculant dosages, initial heavy metal concentrations, $\mathrm{pH}$ values, and reaction times were examined and evaluated using synthetic wastewater samples. The performances obtained under the optimal operational conditions were compared with those of the actual wastewater samples.

\section{Material and methods}

\subsection{Materials}

Bioflocculant QZ-7 was produced from B. salmalaya 139SI. ${ }^{22}$ Heavy metal compounds including arsenite, lead acetate, copper sulfate, cadmium chloride, and zinc sulfate were used to prepare heavy metal stock solutions, and they were of analytical grade. Solutions of $1 \mathrm{M}$ of $\mathrm{HCl}$ and $\mathrm{NaOH}$ were used for $\mathrm{pH}$ adjustment. Nitric acid was used for digestion process. Industrial wastewater samples were obtained from the Perlis state of Malaysia. Inductively coupled plasma mass spectrometry (AAS; Model AA 6300, Shimadzu, Japan) was performed to determine heavy metal concentration before and after adsorption. $\mathrm{pH}$ of the prepared solution was measured through a digital $\mathrm{pH}$ meter (BP3001 Trans instrument) using a calibrated electrode with standard buffer solutions.

\subsection{Characterization of bioflocculant QZ-7}

2.2.1 Biochemical analysis. A total of $2.74 \mathrm{~g}$ of purified QZ-7 was obtained from $1 \mathrm{~L}$ of fermented broth. The pure bioflocculant solution was analyzed using the anthrone method for total carbohydrate content, expending glucose as the standard solution, whereas the carbazole-sulfuric acid method was used to determine uronic acid according to the work of Chaplin and Kennedy. ${ }^{23}$ Bradford assay was performed with bovine serum albumin as the standard solution to determine the total protein quantity. ${ }^{24}$

2.2.2 Fourier-transform infrared spectroscopy (FTIR). QZ-7 sample was characterized using FTIR spectroscopy (PerkinElmer spectrum 400) to determine the type of functional group. The dried pure bioflocculant sample was mixed with potassium bromide $(\mathrm{KBr})$ powder and hard-pressed into pellet discs. FTIR spectra were triplicated and determined in the frequency range of $4000-400 \mathrm{~cm}^{-1}$ under ambient conditions, ${ }^{25}$ while the image resolution was set at $600 \mathrm{dpi}$.

2.2.3 Scanning electron microscopy-energy dispersive X-ray (SEM-EDAX). SEM images were obtained at $2 \mathrm{kV}$ (HITACHISU8220, Japan). EDX measurements were obtained through 
an X-ray detector and examined using the Aztec 22650005761133539 software.

2.2.4 Thermogravimetric analysis (TGA). Approximately $10 \mathrm{mg}$ of purified QZ-7 was examined using a TGA analyzer (PerkinElmer TGA 4000) at the temperature range between $50{ }^{\circ} \mathrm{C}$ and $800{ }^{\circ} \mathrm{C}$ and at a heating degree of $10{ }^{\circ} \mathrm{C} \mathrm{min}^{-1}$ in a nitrogen gas flow rate of $20 \mathrm{~mL} \mathrm{~min}^{-1}$.

\subsection{Factors affecting bioflocculant performance}

2.3.1 Effect of bioflocculant dosage on flocculation efficiency. The optimal concentration of QZ-7 was investigated. A jar-test was used for the clarifying kaolin clay suspension $(4 \mathrm{~g}$ $\mathrm{L}^{-1}$ ) at a neutral $\mathrm{pH}$ of 7 . Various dosages of pure bioflocculant (10 $\left.\mathrm{mg} \mathrm{L}^{-1}\right)$ were used $\left(0.1 \mathrm{mg} \mathrm{mL}^{-1}\right.$ to $\left.6 \mathrm{mg} \mathrm{mL}^{-1}\right)$. The samples of kaolin clay suspension mixtures containing $100 \mathrm{~mL}$ ( $4 \mathrm{~g} \mathrm{~L}^{-1}, \mathrm{pH} 7$ ) of bioflocculant from $0.1 \mathrm{mg} \mathrm{mL}^{-1}$ to $6 \mathrm{mg} \mathrm{mL}^{-1}$ concentrations and $3 \mathrm{~mL}$ of $1 \% \mathrm{CaCl}_{2}$ were stirred vigorously and kept standing for 2-5 min. Calcium ions were added to neutralize the negative repulsion charges for facilitating enhanced flocculation. Optical density (OD) of the clarified solution was tested at $550 \mathrm{~nm}$. A control experiment was also organized, and the bioflocculant QZ-7 solution was replaced with distilled water. Flocculating activity was estimated according to the following eqn (1): ${ }^{26}$

$$
\text { Flocculating activity in } \%=\frac{A_{\mathrm{c}}-B_{\mathrm{s}}}{A_{\mathrm{c}}} \times 100
$$

where, $A_{\mathrm{c}}$ and $B_{\mathrm{s}}$ are the control sample and OD at $550 \mathrm{~nm}$, respectively.

2.3.2 Effect of $\mathbf{p H}$ on flocculating efficiency. To evaluate the effect of $\mathrm{pH}$ on the flocculating activities of QZ-7, the $\mathrm{pH}$ variation of the kaolin suspensions was adjusted between 2 and 11 using $\mathrm{HCl}$ or $\mathrm{NaOH}$. The significance of using a wide range of $\mathrm{pH}$ measurements was to regulate the condition that bears the flocculation process taking place by the support of the bioflocculant and obtain an optimal range where it best performed. A control experiment was also organized, and the bioflocculant QZ-7 solution was replaced with distilled water. Flocculating activity was estimated according to the above eqn (1). ${ }^{26}$

2.3.3 Cation effects on flocculating activities of bioflocculant QZ-7. The influences of different cations on the flocculation activity of QZ-7 were studied by the addition of $\mathrm{CaCl}_{2}, \mathrm{KCl}, \mathrm{NaCl}, \mathrm{LiCl}, \mathrm{MnCl}_{2}, \mathrm{MgCl}_{2}, \mathrm{AlCl}_{3}$ and $\mathrm{FeCl}_{3}$ at a concentration of $1 \mathrm{mM}$. Flocculating efficiency was also measured. ${ }^{27}$ The measurement of flocculating activities was conducted in the same manner as described in Section 2.3.1.

\subsection{Factors affecting heavy metal adsorption}

Removal of heavy metals using a bioflocculant was measured according to the work of Lin and Harichund. ${ }^{28}$ The metal salts used comprised copper sulfate, lead acetate, sodium arsenate, zinc sulfate, and cadmium chloride (Sigma Co). The effects of different initial concentrations of heavy metals $(20,40,60,80$, and $100 \mathrm{mg} \mathrm{L}^{-1}$ ), bioflocculant concentrations (20, 40, 60, 80, and $100 \mathrm{mg} \mathrm{L}^{-1}$ ), and $\mathrm{pH}$ values (3, 5, 7, and 9) on metal adsorption were examined. QZ-7 solutions $(5 \mathrm{~mL})$ were added through a dialysis tube in flasks having $100 \mathrm{~mL}$ of each metalsalt solution and kept for $24 \mathrm{~h}$ at room temperature with shaking at $100 \mathrm{rpm}$. Next, $2 \mathrm{~mL}$ of each solution was filtered through an Amicon filter (Centrifree) and then acidified with $1 \%$ nitric acid solution for residual metal determination. The metal amounts removed from the samples tested, that is, the bound polymers were measured previously, whereas those that remained after $24 \mathrm{~h}$ were detected using inductively coupled plasma mass spectrometry (AAS; Model AA 6300, Shimadzu, Japan); the removal percentage rate for each element was calculated. ${ }^{2}$ Control (5 mL of deionized water) solutions were also prepared in the dialysis tube for different metal-salt solutions. Removal percentage $(R)$ is expressed by eqn (2):

$$
R=\left(\left(C_{\mathrm{i}}-C_{\mathrm{e}}\right) / C_{\mathrm{i}}\right) \times 100
$$

Here, $C_{\mathrm{i}}$ and $C_{\mathrm{e}}$ correspond to the original and equilibrium metal concentrations.

\subsection{Removal of heavy metals from industrial wastewater using bioflocculant QZ-7}

Wastewater from the rubber industry was selected for the experiments. Removal efficiency analysis was performed as stated by the standard methods for examination of water and wastewater. $^{29}$ Filtered wastewater samples $(100 \mathrm{~mL})$ were poured into a dialysis tube; different bioflocculant concentrations $\left(20,40\right.$, and $60 \mathrm{mg} \mathrm{L^{-1 }}$ ) were added and stirred with a magnetic stirrer for $15 \mathrm{~min}$ at $100 \mathrm{rpm}$, slowly stirred for $5 \mathrm{~min}$ at $50 \mathrm{rpm}$, and allowed to settle for $15 \mathrm{~min}$. The volume of the supernatant was filtered through a filter paper and used for heavy metal analysis before and after bioflocculant treatment through inductively coupled plasma mass spectrometry (AAS; Model AA 6300, Shimadzu, Japan); the metal removal percentage rate of each element was also calculated. ${ }^{30}$ Controls ( $5 \mathrm{~mL}$ of deionized water) were also prepared in the dialysis tube for different metal-salt solutions. Removal percentage $(R)$ was expressed as eqn (2).

\subsection{Statistical analysis}

Statistical analyses for the data collected were analysed using SPSS statistical version 25 software. Minimum three measurements were made to detect variability and to avoid biases. Oneway ANOVA, a multiple comparison post-hoc test, was used for the determination of differences in each assay for cases of equality of variance assumed or not assumed. Significant differences were analysed through analysis of variance ANOVA for the basis of making conclusion and predication. ${ }^{31,32}$

\section{Results and discussion}

\subsection{Characterization of bioflocculant QZ-7}

3.1.1 Qualitative analysis. The dried and purified bioflocculant product was whitish with a powdery form. Chemical analysis indicated the constituent total carbohydrates, proteins, and uronic acid chromogenic reaction, as shown in Table 1 . The 
Table 1 Qualitative analysis of bioflocculant QZ-7

\begin{tabular}{lll}
\hline Component type & Analytical method & Occurrence \\
\hline Polysaccharide & Anthrone test & + \\
Protein & Bradford test & + \\
Uronic acid & Carbazole-sulfuric acid test & + \\
\hline
\end{tabular}

major components of the bioflocculant QZ-7 were polysaccharides, proteins, and uronic acid.

3.1.2 Fourier-transform infrared spectroscopy (FTIR). The ability of a bioflocculant to capture pollutants not only depends greatly on molecular weight but also on the available functional groups, especially some charged ionic groups. ${ }^{33,34}$ Therefore, the FTIR spectra analysis of the bioflocculant in this study showed the presence of functional groups related to sugars and proteins. As shown in Fig. 1, a strong absorption peak is observed at $3420.56 \mathrm{~cm}^{-1}$ generated by the stretching vibration of the hydroxyl $(-\mathrm{OH})$ or amino $(-\mathrm{NH})$ groups. In contrast, the maximum band at $2929.82 \mathrm{~cm}^{-1}$ reflected the stretching vibration in the $\mathrm{CH}_{3}$ groups, while the stretching band of $-\mathrm{CH}_{2}$ was found at $2437.35 \mathrm{~cm}^{-1} \cdot{ }^{35}$ The absorption peak at $1658.90 \mathrm{~cm}^{-1}$ corresponded to the presence of carbonyl groups, indicating a characteristic vibration of the $\mathrm{C}=\mathrm{O}$ stretching in the $-\mathrm{CONH}$ group in proteins and amino sugars. ${ }^{36}$ The band numbers between 1187 and $900 \mathrm{~cm}^{-1}$ indicated significantly different sugar derivatives. ${ }^{37}$ The band at $1109.66 \mathrm{~cm}^{-1}$ was ascribed to the asymmetrical stretching of the $\mathrm{C}-\mathrm{O}-\mathrm{C}$ ester linkage. The presence of a $\beta$-glycoside bond between the sugar monomers was indicated by small absorption bands at $618.50 \mathrm{~cm}^{-1}, 535.79 \mathrm{~cm}^{-1}$ and $478.32 \mathrm{~cm}^{-1}$. The presence of $-\mathrm{OH}, \mathrm{NH}-, \mathrm{COOH}-$ and $\mathrm{COO}-$ groups in the bioflocculant molecules is important for determining the flocculating activity, while the $\mathrm{H}^{+}$and $\mathrm{OH}^{-}$groups on the surface of the suspended particles may form hydrogen bonds when the bioflocculant chains approach the surface of the particles. ${ }^{38,39}$

3.1.3 Scanning electron microscopy. B. salmalaya strain 139SI produces an extracellular metabolite, that is, bioflocculant QZ-7. The SEM image in Fig. 2a shows the brickshaped structure of bioflocculant QZ-7.

3.1.4 SEM-energy dispersive X-ray. Fig. $2 \mathrm{~b}$ shows the elemental analysis of the bioflocculant on the basis of SEM-EDX testing. $\mathrm{C}, \mathrm{O}, \mathrm{N}, \mathrm{P}$, and $\mathrm{S}$ in this macromolecule accounted for $55.74 \%, 42.74 \%, 0.54 \%, 0.93 \%$, and $0.06 \%$, of the bioflocculant, respectively. Salehizadeh et al. $^{\mathbf{4 0}}$ reported the presence of phosphorus and sulfur in low quantities in a bioflocculant. The bioflocculants containing sulfur are a perfect substrate for lead $\left(\mathrm{Pb}^{2+}\right)$ adsorption because the ions possess high affinity towards many heavy metals including $\mathrm{Pb}^{2+} \cdot{ }^{41}$

3.1.5 Thermogravimetric determination of purified QZ-7. The bioflocculant QZ-7 was tested to elucidate its thermogravimetric behavior at different temperatures. ${ }^{42}$ The results are depicted in Fig. 3 to assist in recognizing its pyrolysis property after exposure to significantly elevated temperatures. Fig. 3 shows a weight loss of QZ-7 (\%) under the effect of temperature between 50 and $800{ }^{\circ} \mathrm{C}$. The maximum weight loss $(61.13 \%)$ of QZ-7 was reported at $480{ }^{\circ} \mathrm{C}$, while QZ-7 was completely pyrolyzed at a temperature higher than $480{ }^{\circ} \mathrm{C}$; the weight loss was approximately $5 \%$ at $100{ }^{\circ} \mathrm{C}, 12.14 \%$ at $200{ }^{\circ} \mathrm{C}$, and $25 \%$ at $300{ }^{\circ} \mathrm{C}$. TGA of the bioflocculant QZ-7 exhibited thermo-labile and thermo-stable molecular contents, showing the combination of sugar and protein substances, as indicated by examination.

The first weight decrease may be due to the loss of available moisture or the presence of carboxyl and hydroxyl groups in the protein portions related to the glycoprotein-like molecules of QZ-7. Analogous observations were reported by Wang et al. ${ }^{\mathbf{1 6}}$

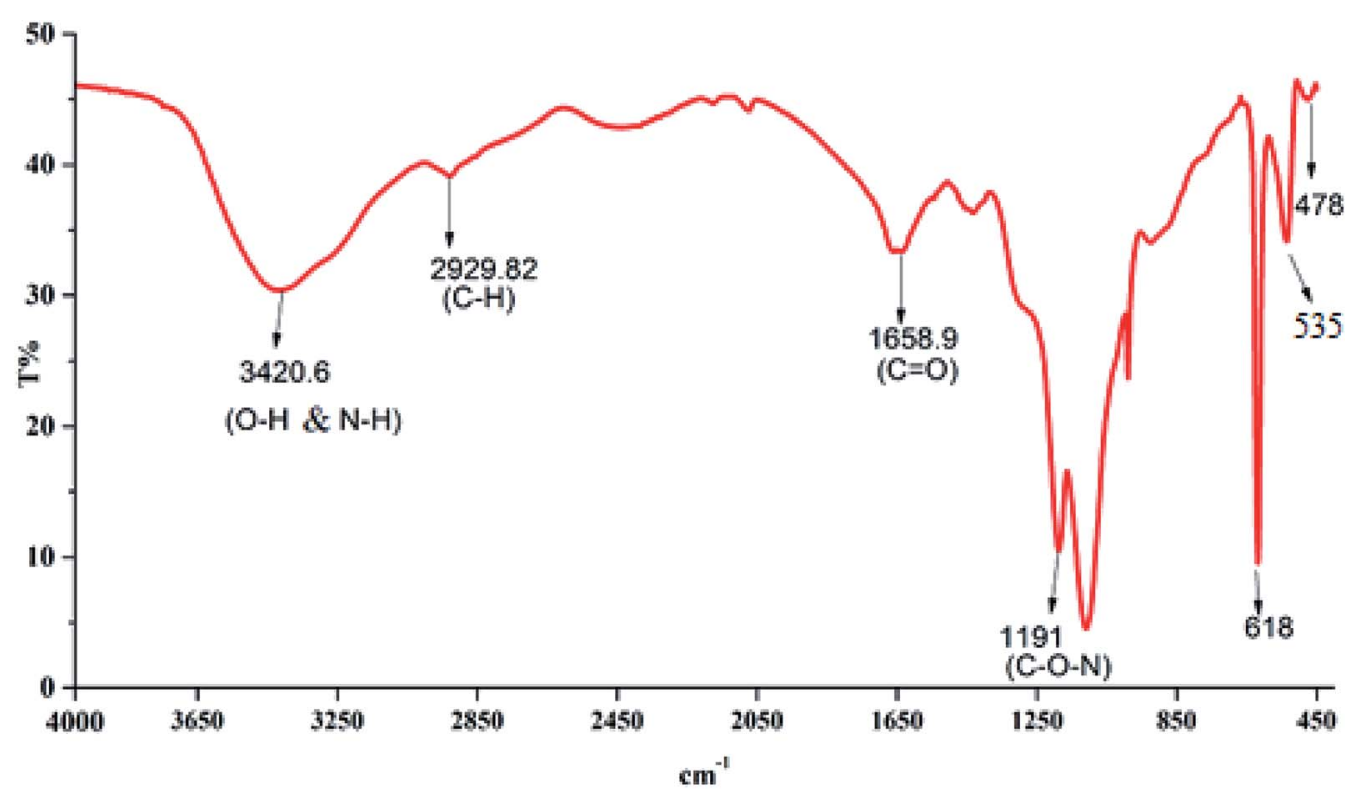

Fig. 1 Fourier-transform infrared spectra. 
with respect to the bioflocculant gained from the mixed consortium of bacteria.

\subsection{Factors affecting flocculating performance of bioflocculant}

3.2.1 Effect of pH. Bioflocculant QZ-7 has a relatively wide $\mathrm{pH}$ tolerance ranging from acidic to slightly alkaline conditions. As shown in Fig. 4, the bioflocculant QZ-7 was found to be fairly steady at a wider $\mathrm{pH}$ range of $4-7$, and over $70 \%$ flocculating activity was observed at this $\mathrm{pH}$ range with significant different performances $(p<0.00)$. As shown in Table 2 , the highest flocculating activity was achieved at $\mathrm{pH} 7$ with a mean difference of about $91.5 \%$ from the lowest activity measured at $\mathrm{pH} 2-3$ and 11 $(p<0.05)$. Consequently, multiple comparison analysis revealed that $\mathrm{pH} 5$ and $\mathrm{pH} 6$ have the same effect on the flocculating activity of QZ-7.

3.2.2 Effect of bioflocculant dosage. The bioflocculant dosage concentration is one of the dynamic parameters deliberated during the investigation of the optimum conditions in coagulation-flocculation development. ${ }^{43}$ The performance in flocculation decreases due to the inadequate dose of a bioflocculant. ${ }^{43}$ Consequently, the bioflocculant optimal dosage should be set up to support the reduction of costs and achieve a better performance in treatment processes. In this section, a kaolin suspension was used to determine the optimal bioflocculant dosage for heavy metal removal. Fig. 5 shows the correlation between bioflocculant dosage and kaolin suspension removal. The bioflocculant concentration ranged between $0.1 \mathrm{mg} \mathrm{mL}^{-1}$ and $6 \mathrm{mg} \mathrm{mL}^{-1}$. The maximum removal value for kaolin suspension (93.66\%) was reported at $2 \mathrm{mg} \mathrm{mL}^{-1}$ of the bioflocculant; decrease in turbidity may be caused by the adsorption of excess bioflocculant on the colloidal surfaces, causing colloid destabilization and thus blocking the available sites on the surface of particles for the improvement in the interparticle bridges. ${ }^{44}$ In contrast, the removal was reduced at a bioflocculant dosage higher than $2 \mathrm{mg} \mathrm{mL}^{-1}$. Gong et al. ${ }^{45}$ reported that an inadequate dosage of a bioflocculant used during treatment can lead to a poor bridging phenomenon, thus resulting in low flocculation activity.

Table 3 shows that the result obtained is in accordance with the reported findings for the flocculation performance of

(a)

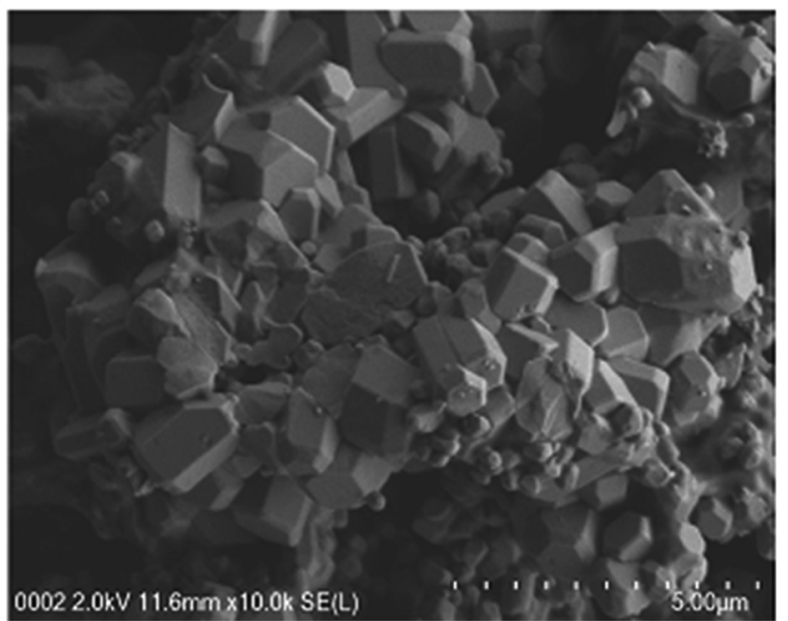

(b)

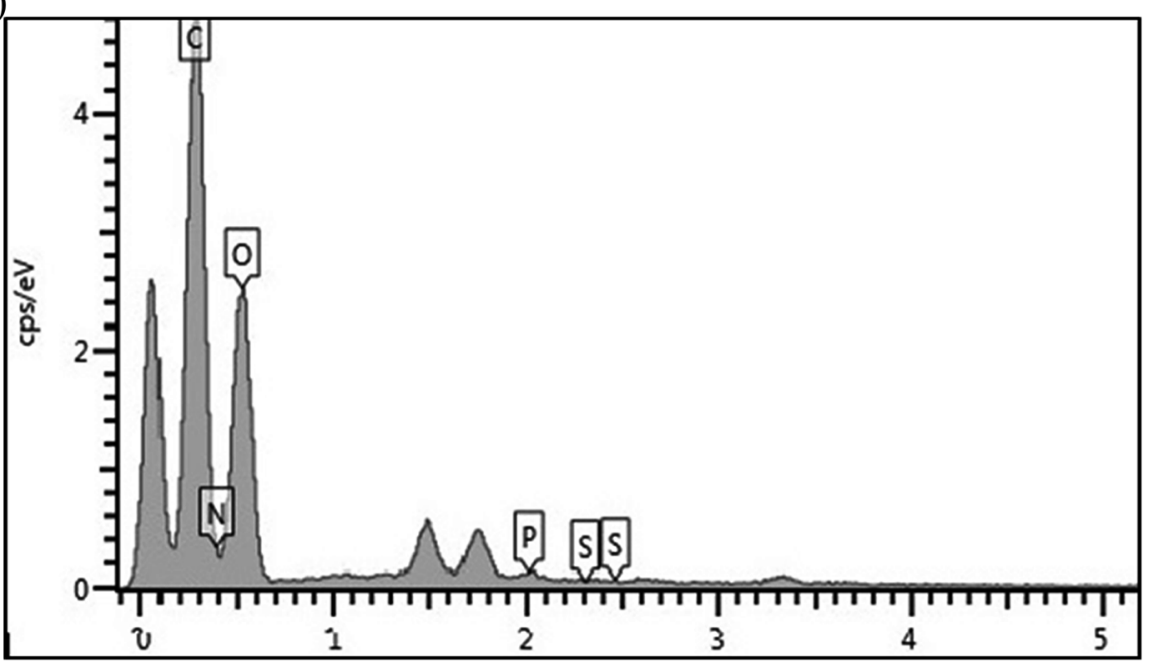

Fig. 2 (a) SEM micrograph of bioflocculant QZ-7. (b) EDAX of bioflocculant QZ-7. 


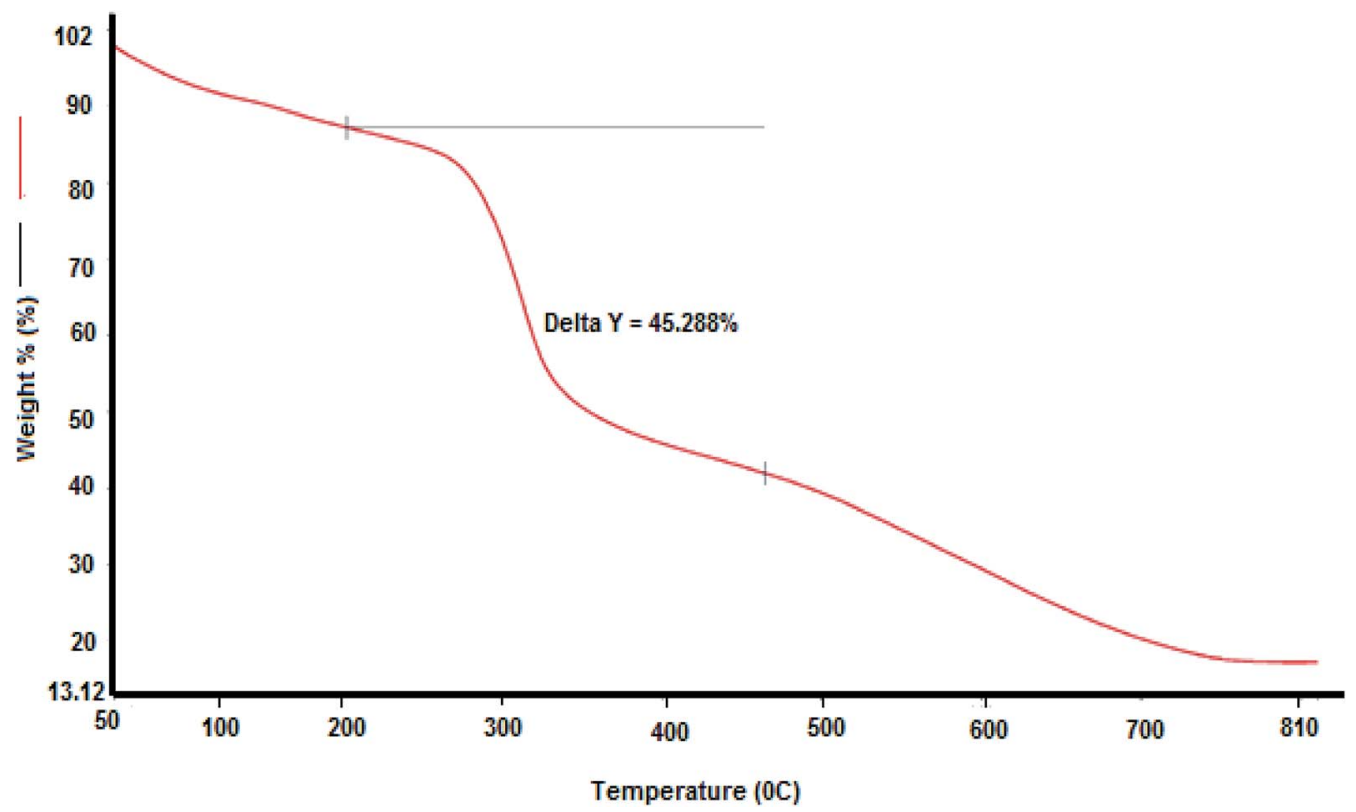

Fig. 3 Thermogravimetric analysis of the purified QZ-7.

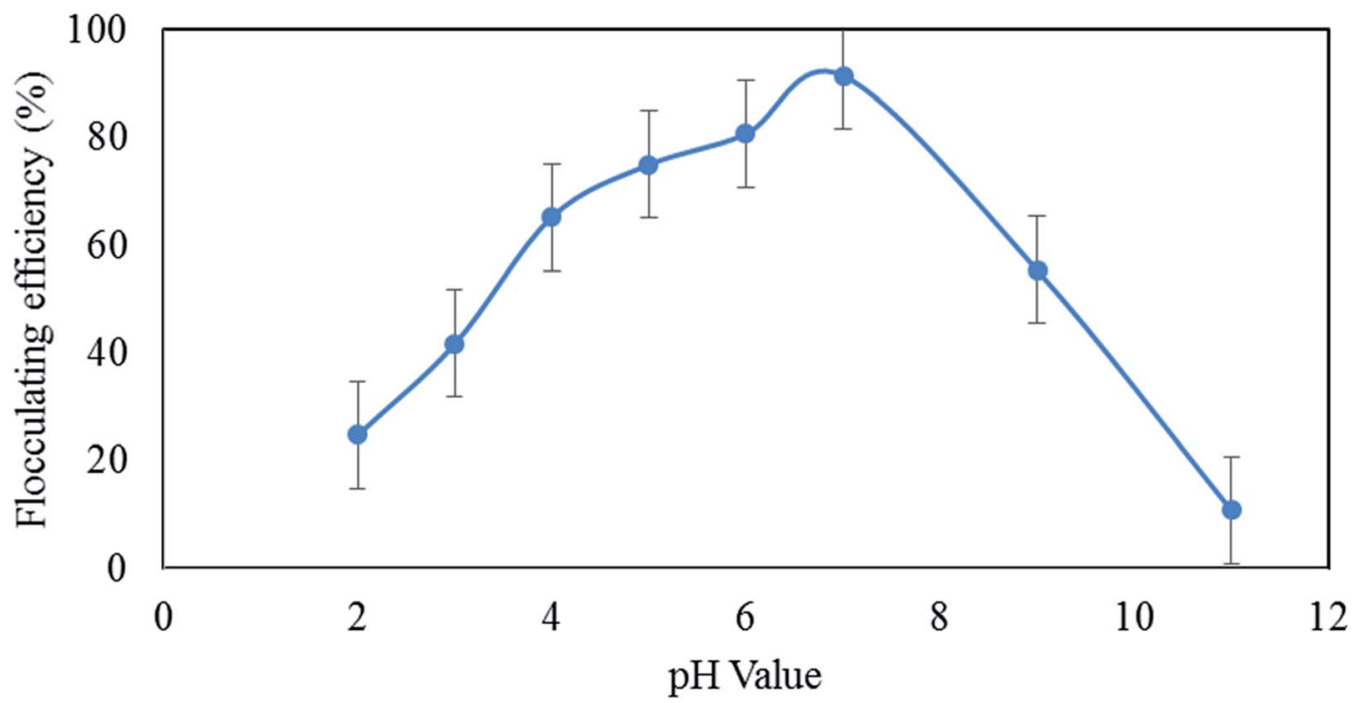

Fig. $4 \mathrm{pH}$ stability of the purified bioflocculant QZ-7.

different concentrations of bioflocculants with significant differences $(p<0.00)$.

3.2.3 Cation effects on flocculation efficiency. Cations improved the coagulation-flocculation process of neutralizing and destabilizing the negatively charged residues of bioflocculant functional groups through linking particle bonds to the kaolin suspension. ${ }^{46}$ For instance, Fig. 6 shows that monovalent and divalent cations, including $\mathrm{Al}^{3+}$, can stimulate the flocculating activity to a significant extent compared to trivalent $\mathrm{Fe}^{3+}$ cations. The maximum flocculating efficiency (92.6\%) was detected for $\mathrm{Ca}^{2+}$, followed by $\mathrm{Al}^{3+}$ (83.3\%), $\mathrm{Mn}^{2+}$ (75.6\%), $\mathrm{K}^{+}$ (71.6\%), $\mathrm{Mg}^{2+}$ (71.4\%), $\mathrm{Na}^{+}(67.7 \%)$, and $\mathrm{Li}^{+}$(64\%). These results are analogous to those reported by Okaiyeto et al. (2013),
Wang et al. (2011), and Zheng et al. (2008). ${ }^{\mathbf{1 6 , 4 6 , 4 7}}$ They reported that various cations, such as $\mathrm{Ca}^{2+}, \mathrm{Mn}^{2+}$, and $\mathrm{Al}^{3+}$, increased the flocculation activity of the bioflocculants produced by Micrococcus sp. and Halomonas sp., xn11 and xn7, and the mixed

Table 2 Analysis of variance for the effect of $\mathrm{pH}$ on flocculating performance

\begin{tabular}{lrrrrr}
\hline & Sum of squares & df & Mean square & F & Sig. \\
\hline Between groups & 16405.203 & 7 & 2343.600 & 2014.895 & 0.000 \\
Within groups & 18.610 & 16 & 1.163 & & \\
Total & 16423.813 & 23 & & &
\end{tabular}




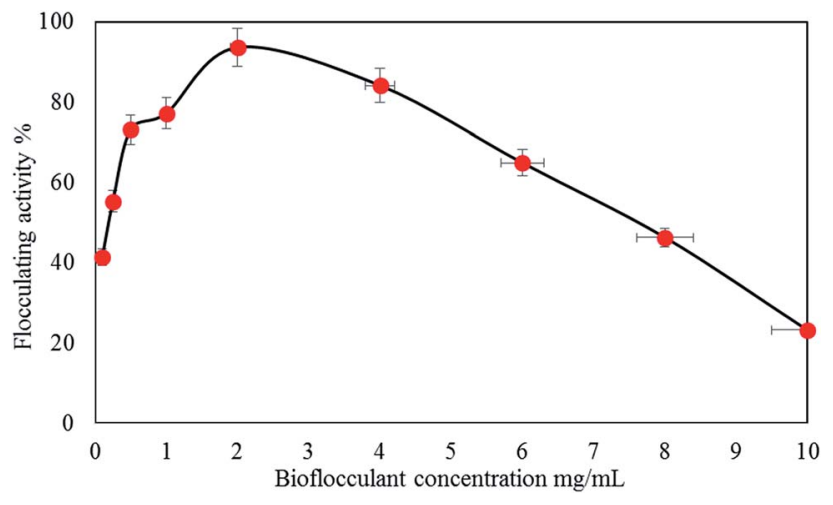

Fig. 5 Bioflocculant QZ-7 dosage effect on flocculating activity.

Table 3 Analysis of variance for the effect of bioflocculant QZ-7 concentration

\begin{tabular}{lrrrrr}
\hline & Sum of squares & df & Mean square & F & Sig. \\
\hline Between groups & 12241.856 & 8 & 1530.232 & 834.503 & 0.000 \\
Within groups & 33.007 & 18 & 1.834 & & \\
Total & 12274.863 & 26 & & &
\end{tabular}

culture of Bacillus sphaeicus $\mathrm{F} 6$ and Rhizobium radiobacter F2. The bioflocculant produced by aquatic bacteria, Oceanobacillus sp., which was the most stimulated by cations, such as calcium chloride and aluminum chloride, was also detected. ${ }^{48}$ The bioflocculants produced by Bacillus sp. and Virgibacillus sp. were interactive, increasing the flocculating activity under the influence of $\mathrm{Ca}^{2+}, \mathrm{Mg}^{2+}$, and $\mathrm{Mn}^{2+} .{ }^{48,49}$ Calcium ions were more active and improved the formation of larger flocs when compared with other cations. Therefore, calcium ions were selected as the coagulant support for further experiments.

The statistical analysis presented in Table 4 indicates that there is a significant difference $(p<0.000)$ between different cations.

\subsection{Application of bioflocculant QZ-7}

3.3.1 Influence of $\mathrm{pH}$ on heavy metal adsorption. $\mathrm{pH}$ is recognized as the most essential parameter due to the significant changes in $\mathrm{pH}$ that occur during heavy metal sorption. $\mathrm{pH}$

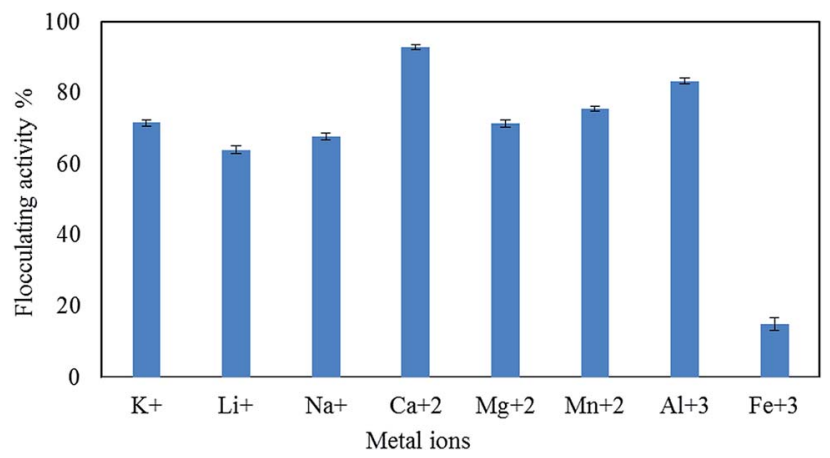

Fig. 6 Metal ion effect on the flocculating activity of pure QZ-7.
Table 4 Analysis of variance for the effect of cations on flocculating activity

\begin{tabular}{lrrrrr}
\hline & Sum of squares & df & Mean square & F & Sig. \\
\hline Between groups & 11327.947 & 7 & 1618.278 & 1016.387 & 0.000 \\
Within groups & 25.475 & 16 & 1.592 & & \\
Total & 11353.422 & 23 & & &
\end{tabular}

is directly linked to the interaction competency of hydrogen ions with the metal ions on the active sites of the biosorbent surfaces. ${ }^{50}$ Spectroscopic analysis (FTIR) indicated that the pure bioflocculant QZ-7 possessed an assortment of functional groups, including carboxyl, hydroxyl, and amino groups, which are virtually intricate in terms of binding mechanism potentials. ${ }^{22}$ These functional groups contribute to metal-ion binding and are dependent on the $\mathrm{pH}$ values of the aqueous solution. The influence of $\mathrm{pH}$ on heavy metal adsorption, such as those of As, $\mathrm{Cd}^{2+}, \mathrm{Cu}^{2+}, \mathrm{Pb}^{2+}, \mathrm{Zn}^{2+}$, and $\mathrm{Hg}^{2+}$, by the bioflocculant QZ-7 was investigated at $\mathrm{pH} 3-9$. In Fig. 7, the heavy metal adsorption shows an increasing trend when the $\mathrm{pH}$ value is increased from 3 to 9, which is similar to the study of Dobrowolski et al. ${ }^{35}$ The highest adsorptions of $\mathrm{Zn}^{2+}$ and As were reported at $\mathrm{pH}$, whereas the highest adsorptions of $\mathrm{Cu}^{2+}, \mathrm{Pb}^{2+}$, and $\mathrm{Cd}^{2+}$ were reported at $\mathrm{pH}$ 9. The highest adsorption of $\mathrm{Hg}^{2+}$ occurred at $\mathrm{pH}$ 5. Regarding the analysis of variance of the effect of different $\mathrm{pH}$ values on heavy metal removal efficiency, the results are presented in Table 5. It was revealed that different $\mathrm{pH}$ values have a significant difference $(p<0.00)$. The adsorption of heavy metals was high at neutral and alkaline $\mathrm{pH}$ values, and high proton concentrations at acidic $\mathrm{pH}$ values competed for the same anionic sites of the polymer as divalent cations. Proton mass contributes to the preferred binding, resulting in low divalent cation binding. ${ }^{51}$ For instance, the increase in $\mathrm{pH}$ towards the optimal value, which contrasted from one metal ion to another, and the saturated superficial adsorption by negative charges led to increased efficiency of positive charges to bind and adsorb metal ions. ${ }^{52}$ At a $\mathrm{pH}$ higher than their optimal value, hydroxide metals can be formed, and the adsorption sites on the surface fail to bind the adsorbent. ${ }^{53}$

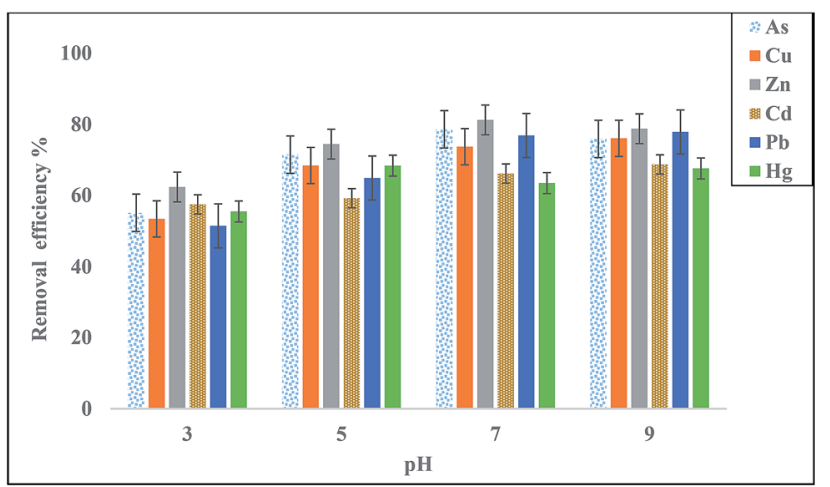

Fig. 7 Effect of $\mathrm{pH}$ on heavy metal adsorption using $20 \mathrm{mg} \mathrm{L}^{-1}$ bioflocculant QZ-7. 
Table 5 Analysis of variance for the effect of $\mathrm{pH}$ on arsenate removal efficiency

\begin{tabular}{lrrrrr}
\hline & Sum of squares & df & Mean square & F & Sig. \\
\hline Between groups & 2555.898 & 6 & 425.983 & 274.912 & 0.000 \\
Within groups & 21.693 & 14 & 1.550 & & \\
Total & 2577.591 & 20 & & &
\end{tabular}

3.3.2 Effect of bioflocculant QZ-7 concentration on heavy metal adsorption. The results in Fig. 8 show that the bioflocculant displayed better efficiency in heavy metal removal. As shown in Fig. 8, although the maximum removal for As $(81 \%)$, $\mathrm{Cu}^{2+}(84 \%), \mathrm{Cd}^{2+}(77 \%), \mathrm{Zn}^{2+}(78.5 \%)$ and $\mathrm{Pb}^{2+}(71.5 \%)$ was reported at $60 \mathrm{mg} \mathrm{L}^{-1}$ of the bioflocculant concentration, significant removal for heavy metals (As (63\%), $\mathrm{Cu}^{2+}(60 \%), \mathrm{Cd}^{2+}$ (55\%), $\mathrm{Zn}^{2+}(44 \%)$ and $\left.\mathrm{Pb}^{2+}(54 \%)\right)$ was also obtained at a lower concentration of the bioflocculant $\left(20 \mathrm{mg} \mathrm{L}^{-1}\right)$. Similar results were also reported by Das and Santra. ${ }^{54}$ The increased heavy metal removal efficiencies at low bioflocculant concentrations will significantly enhance the development of industrial effluent wastewater treatment. Besides, in accordance with the multiple analyses shown in Table 6 , there is a significant difference $(p<$ 0.05) for different QZ-7 concentrations on heavy metal removal efficiency.

3.3.3 Effect of metal concentration on removal efficiency using $60 \mathrm{mg} \mathrm{L}^{-1}$ of bioflocculant QZ-7. The results presented in Fig. 9 show that heavy metal adsorption increased with increasing initial concentrations between 10 and $100 \mathrm{mg} \mathrm{L}^{-1}$, as indicated by the maximum removal of As $(94.3 \%)$ at $60 \mathrm{mg} \mathrm{L}^{-1}$ and the optimum removal of $\mathrm{Cu}^{2+}$ (85.2\%), $\mathrm{Cd}^{2+}(84.5 \%), \mathrm{Zn}^{2+}$ (84.5), and $\mathrm{Pb}^{2+}(82.76 \%)$ at $100 \mathrm{mg} \mathrm{mL}^{-1}$. The improvement in metal adsorption may be due to the increase in electrostatic interactions and the constantly low affinity of the linking sites for metal ions. ${ }^{55}$ Hence, the presence of sulfur in a bioflocculant enhances its heavy metal capacity and makes it an excellent substrate for applications in heavy metal sequestration. ${ }^{56}$

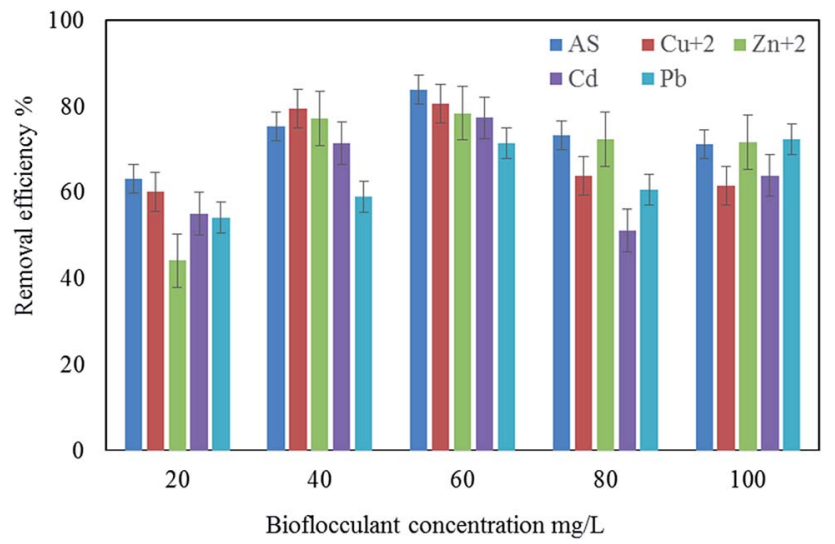

Fig. 8 Effect of bioflocculant QZ-7 concentration on the removal efficiency of heavy metals.
Table 6 Analysis of variance for the effect of QZ-7 concentration on the removal efficiency of heavy metals

\begin{tabular}{lrrrrr}
\hline & Sum of squares & df & Mean square & F & Sig. \\
\hline Between groups & 740.568 & 5 & 148.114 & 35.041 & 0.000 \\
Within groups & 50.723 & 12 & 4.227 & & \\
Total & 791.291 & 17 & & &
\end{tabular}

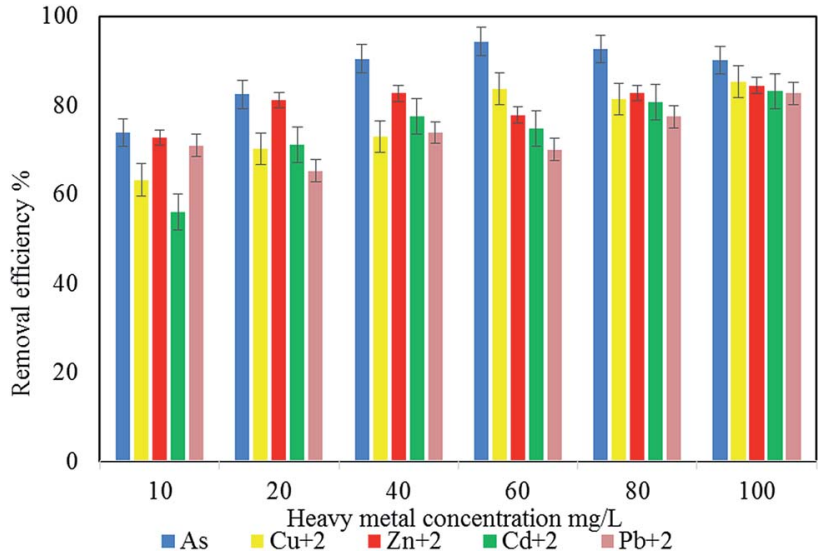

Fig. 9 Effect of metal concentration on the efficiency of the removal of heavy metals.

Based on the multiple analyses of the effect of heavy metal concentration on the bioflocculant adsorption efficiency shown in Table 7 , there is a significant difference $(p<0.05)$ for the different concentrations of heavy metals.

\subsection{Removal of heavy metals from industrial wastewater using bioflocculant QZ-7}

Rapid initial adsorption of the heavy metals can be achieved by the affinity action of amino, carboxyl and hydroxyl groups present in a bioflocculant. ${ }^{30}$ The treatment of industrial effluents with the bioflocculant QZ-7 at different concentrations, i.e., 20, 40, and $60 \mathrm{mg} \mathrm{L}^{-1}$ showed effective flocculation with concomitant reduction in heavy metals. Similarly, Fig. 10 depicts the effect of adsorbent dosage on the adsorption of heavy metals by bioflocculant QZ-7. For example, As removal increased from $71.9 \%$ to $89.85 \%$ with the amount of adsorbent concentration, whereas $\mathrm{Zn}^{2+}$ removal also increased from $63.85 \%$ to $77.4 \%$. On the other hand, $\mathrm{Cu}^{2+}$ removal slightly increased from $53.2 \%$ to $58.4 \%$.

Table 7 Analysis of variance for the effect of heavy metal concentration on QZ-7 adsorption efficiency

\begin{tabular}{lrrcll}
\hline & Sum of squares & df & Mean square & F & Sig. \\
\hline Between groups & 563.465 & 5 & 112.693 & 26.520 & 0.000 \\
Within groups & 50.991 & 12 & 4.249 & & \\
Total & 614.457 & 17 & & &
\end{tabular}




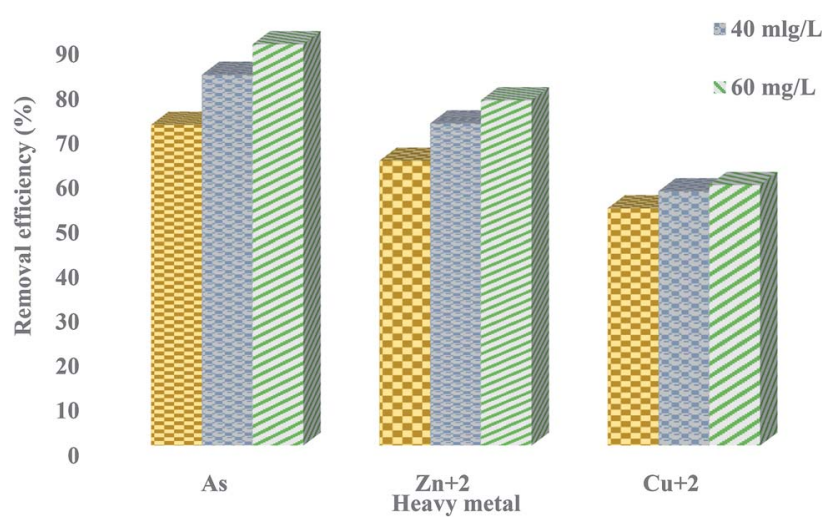

Fig. 10 Removal efficiency of heavy metals using $20 \mathrm{mg} \mathrm{L}^{-1}$ $40 \mathrm{mg} \mathrm{L}^{-1}$ and $60 \mathrm{mg} \mathrm{L}^{-1}$ of bioflocculant QZ-7.

\section{Conclusion}

The present study investigated the performance of a new polymeric bioflocculant QZ-7 for the removal of heavy metals from industrial wastewater. The removal efficiency for $\mathrm{As}^{3+}, \mathrm{Cu}^{2+}$, $\mathrm{Zn}^{2+}, \mathrm{Cd}^{2+}$, and $\mathrm{Pb}^{2+}$ was evaluated under varying experimental conditions, such as $\mathrm{pH}$, incubation time, initial concentration of metal ions, and adsorbent dosage. Maximum flocculating efficiency (92.9\%) was achieved for $\mathrm{Ca}^{2+}$ at $\mathrm{pH} 7.0 \pm 0.2$ followed by $\mathrm{Al}^{3+}(83.3 \%) ; \mathrm{Mn}^{2+}, \mathrm{K}^{+}$, and $\mathrm{Mg}^{2+}$ (over 70\%); $\mathrm{Na}^{+}$and $\mathrm{Li}^{+}$ (above 64\%). The maximum adsorptions of $\mathrm{Zn}^{2+}(81.2 \%)$ and $\mathrm{As}$ (78.6\%) were detected at $\mathrm{pH} 7$, whereas the maximum removal of $\mathrm{Pb}^{2+}(77.9 \%), \mathrm{Cu}^{2+}(76.1 \%)$, and $\mathrm{Cd}^{2+}(68.7 \%)$ was obtained at $\mathrm{pH}$ 9. The results showed that the bioflocculant QZ-7 can be applied for the removal of heavy metals from industrial wastewater within the concentration range from $20 \mathrm{mg} \mathrm{L}^{-1}$ to $60 \mathrm{mg} \mathrm{L}^{-1}$. The bioflocculant was effective in the removal of As, $\mathrm{Zn}^{2+}$, and $\mathrm{Cu}^{2+}$. The findings established that the efficiency of heavy metal removal depends on the dose of low-cost adsorbent and bioflocculant concentrations. The optimum $\mathrm{pH}$ range for heavy metal adsorption ranged from 7 to 9 .

\section{Funding}

This study was supported by the University of Malaya, UMRG Programme under Grant No. RP023A-14 AFR.

\section{Conflicts of interest}

There are no conflicts to declare.

\section{References}

1 K. Okaiyeto, U. U. Nwodo, S. A. Okoli, L. V. Mabinya and A. I. Okoh, MicrobiologyOpen, 2016, 5, 177-211.

2 R. Gourdon, S. Bhende, E. Rus and S. S. Sofer, Biotechnol. Lett., 1990, 12, 839-842.

3 A. Azimi, A. Azari, M. Rezakazemi and M. Ansarpour, ChemBioEng Rev., 2017, 4, 37-59.
4 A. Mukherjee, T. Mandal, A. Ganguly and P. K. Chatterjee, ChemBioEng Rev., 2016, 3, 86-96.

5 M. Anastácio, A. M. dos Santos, M. Aschner and L. Mateus, Toxicol. Rep., 2018, 5, 434-439.

6 V. K. Gupta and I. Ali, Environmental water: advances in treatment, remediation and recycling, Newnes, 2012.

7 F. Wang and Z. Guo, Appl. Clay Sci., 2019, 175, 115-123.

8 K. Nogawa and T. Kido, Toxicology of metals, 1996, pp. 353369.

9 M. Altun, E. Sahinkaya, I. Durukan, S. Bektas and K. Komnitsas, J. Hazard. Mater., 2014, 269, 31-37.

10 H. Salehizadeh and N. Yan, Biotechnol. Adv., 2014, 32, 15061522.

11 M. Dahiru, A. B. N. Kartini and I. Yusoff, $R S C A d v .$, 2019, 9, 15437-15447.

12 L. Xu, X. Xing, J. Liang, J. Peng and J. Zhou, RSC Adv., 2019, 9, 993-1003.

13 S. Cataldo, G. Lazzara, M. Massaro, N. Muratore, A. Pettignano and S. Riela, Appl. Clay Sci., 2018, 156, 87-95.

14 A. H. R. Aljuboori, A. Idris, N. Abdullah and R. Mohamad, Bioresour. Technol., 2013, 127, 489-493.

15 Z. Li, S. Zhong, H.-y. Lei, R.-w. Chen, Q. Yu and H.-L. Li, Bioresour. Technol., 2009, 100, 3650-3656.

16 L. Wang, F. Ma, Y. Qu, D. Sun, A. Li, J. Guo and B. Yu, World J. Microbiol. Biotechnol., 2011, 27, 2559-2565.

17 C. S. Lee, M. F. Chong, J. Robinson and E. Binner, Ind. Eng. Chem. Res., 2014, 53, 18357-18369.

18 D. Zhang, Z. Hou, Z. Liu and T. Wang, Int. J. Min. Sci. Technol., 2013, 23, 521-524.

19 C. Siah Lee, M. Fong Chong, J. P. Robinson and E. Binner, A Review on Development and Application of Plant-Based Bioflocculants and Grafted Bioflocculants, 2014.

20 H. Zhao, H. Liu and J. Zhou, Bioresour. Technol., 2013, 137, 226-232.

21 M. Fujita, M. Ike, S. Tachibana, G. Kitada, S. M. Kim and Z. Inoue, J. Biosci. Bioeng., 2000, 89, 40-46.

22 Z. Abu Tawila, S. Ismail, A. Dadrasnia and M. Usman, Molecules, 2018, 23, 2689.

23 M. F. Chaplin and J. F. Kennedy, Carbohydrate analysis: a practical approach, IRL Press Ltd, 2nd edn, 1994.

24 M. M. Bradford, Anal. Biochem., 1976, 72, 248-254.

25 A. Ugbenyen and A. Okoh, Chem. Biochem. Eng. Q., 2013, 27, 511-518.

26 J. Gao, H.-y. Bao, M.-x. Xin, Y.-x. Liu, Q. Li and Y.-f. Zhang, J. Zhejiang Univ., Sci., B, 2006, 7, 186-192.

27 W. Li, W. Zhou, Y. Zhang, J. Wang and X. Zhu, Bioresour. Technol., 2008, 99, 6893-6899.

28 J. Lin and C. Harichund, Afr. J. Microbiol. Res., 2011, 5, 599607.

29 A. P. H. Association and A. W. W. Association, Standard methods for the examination of water and wastewater, American Public Health Association, 1989.

30 B. Liu, X. Chen, H. Zheng, Y. Wang, Y. Sun, C. Zhao and S. Zhang, Carbohydr. Polym., 2018, 181, 327-336.

31 C. Zhu, C. Chen, L. Zhao, Y. Zhang, J. Yang, L. Song and S. Yang, J. Appl. Phycol., 2012, 24, 1245-1251. 
32 X. Yong, W. Raza, G. Yu, W. Ran, Q. Shen and X. Yang, Bioresour. Technol., 2011, 102, 7548-7554.

33 A. Chen, C. Shang, J. Shao, Y. Lin, S. Luo, J. Zhang, H. Huang, M. Lei and Q. Zeng, Carbohydr. Polym., 2017, 155, 19-27.

34 H. Zhu, Y. Zhang, X. Yang, H. Liu, L. Shao, X. Zhang and J. Yao, J. Hazard. Mater., 2015, 296, 1-8.

35 R. Dobrowolski, A. Szcześ, M. Czemierska and A. JaroszWikołazka, Bioresour. Technol., 2017, 225, 113-120.

36 M. Pathak, H. K. Sarma, K. G. Bhattacharyya, S. Subudhi, V. Bisht, B. Lal and A. Devi, Front. Microbiol., 2017, 8, 170.

37 J. Čopíková, A. S. Barros, I. Šmídová, M. Černá, D. H. Teixeira, I. Delgadillo, A. Synytsya and M. A. Coimbra, Carbohydr. Polym., 2006, 63, 355-359.

38 U. Habiba, T. A. Siddique, T. C. Joo, A. Salleh, B. C. Ang and A. M. Afifi, Carbohydr. Polym., 2017, 157, 1568-1576.

39 D. Soto, J. Urdaneta, K. Pernia, O. León, A. Muñoz-Bonilla and M. Fernández-García, J. Polym. Environ., 2016, 24, 343355.

40 H. Salehizadeh and S. Shojaosadati, Biotechnol. Adv., 2001, 19, 371-385.

41 G. M. Gadd, Curr. Opin. Biotechnol., 2000, 11, 271-279.

42 J. H. Yim, S. J. Kim, S. H. Ahn and H. K. Lee, Bioresour. Technol., 2007, 98, 361-367.

43 M. A. Hassan, T. P. Li and Z. Z. Noor, Journal of Chemical and Natural Resources Engineering, 2009, 4, 43-53.
44 Z. Liang, H. Baoping and L. Hong, Min. Sci. Technol., 2010, 20, 478-484.

45 W.-X. Gong, S.-G. Wang, X.-F. Sun, X.-W. Liu, Q.-Y. Yue and B.-Y. Gao, Bioresour. Technol., 2008, 99, 4668-4674.

46 Y. Zheng, Z.-L. Ye, X.-L. Fang, Y.-H. Li and W.-M. Cai, Bioresour. Technol., 2008, 99, 7686-7691.

47 K. Okaiyeto, U. Nwodo, L. Mabinya and A. Okoh, Int. J. Environ. Res. Public Health, 2013, 10, 5097-5110.

48 C. Sekelwa, U. M. Anthony, M. L. Vuyani and O. I. Anthony, Afr. J. Microbiol. Res., 2013, 7, 2925-2938.

49 U. Nwodo, M. Agunbiade, E. Green, M. Nwamadi, K. Rumbold and A. Okoh, Materials, 2013, 6, 1237-1254.

50 P. Lodeiro, J. Barriada, R. Herrero and M. S. De Vicente, Environ. Pollut., 2006, 142, 264-273.

51 D. Sahoo, R. Kar and R. Das, Bioresour. Technol., 1992, 41, 177-179.

52 G. Bayramoğlu, S. Bektaş and M. Y. Arıca, J. Hazard. Mater., 2003, 101, 285-300.

53 Y. Kacar, Ç. Arpa, S. Tan, A. Denizli, Ö. Genç and M. Y. Arıca, Process Biochem., 2002, 37, 601-610.

54 S. Das and S. Santra, New Frontiers of Environ. Biotechnol. Appl, 2007, vol. 3, pp. 1-10.

55 P. Puranik and K. Paknikar, Biotechnol. Prog., 1999, 15, 228237.

56 K. Kavita, A. Mishra and B. Jha, Carbohydr. Polym., 2013, 94, 882-888. 